\title{
USING CROWDSOURCING TO SUPPORT CIVIC ENGAGEMENT IN STRATEGIC URBAN DEVELOPMENT PLANNING: A CASE STUDY OF OSTRAVA, CZECH REPUBLIC
}

\section{- Barbora Haltofova}

\begin{abstract}
Recently, advances in Information and Communication Technologies (ICTs) have provided opportunities for governments to deploy e-participation to actively engage citizens in public policymaking processes. As often noted, the development towards e-participation not only transforms the nature of government interactions with citizens but also affects the efficiency and effectiveness of public services and thus fosters competitiveness. Crowdsourcing is one mechanism of undertaking e-participation. It is a method for harnessing the collective intelligence of online communities to solve specific problems or produce goods, which has proved to be a successful supplemental public participation tool for city governance, as a way to engage citizens in the process of urban planning. This paper highlights how crowdsourcing can overcome the limitations in a traditional urban planning process. Using Ostrava, Czech Republic as a case study, this paper explores how city government engages citizens in creating the strategic urban development plan. The results show how crowdsourcing contributes to better civic engagement, improves citizens' perceptions of their city, and thus helps to find ways to encourage the competitiveness of the city of Ostrava, which is facing the problem of depopulation.
\end{abstract}

Keywords: crowdsourcing, e-participation, strategic urban development planning, Ostrava, Czech Republic JEL Classification: $\mathrm{H} 83$

\section{INTRODUCTION}

Civic engagement consists of knowledge, discussion, interest, and participation in public affairs, government and policy issues, and the community. Recent trends in information and communication technologies (ICTs) have emphasized the greater involvement of citizens in governance and public policy. As new ICTs and the omnipresent Internet connection offer not only convenient and flexible access to information but also a channel of effective communication, crowdsourcing represents a unique opportunity to connect citizens with government and to engage them.

As stated by Boukhris et al. (2016), citizens' engagement is considered an important dimension for the development of a smart city - a new city model resulting from the rapid development of new technologies and innovation processes. This is confirmed by Gooch et al. (2015), who claim that smart cities must focus on people rather than on technologies, or better, as stated by Desouza \& Bhagwatwar (2014), use the potential of technologies to foster citizens' engagement by deploying technology-enabled participatory platforms for civic engagement. 
In this context, the notion of the wisdom of the crowds (Surowiecki \& Silverman, 2007) has gained importance. Crowdsourcing enables public officials to work outside the traditional structures (Dirks \& Keeling, 2009) and to engage citizens in innovative ways. Towards that end, the purpose of this paper is to report on the crowdsourcing initiative deployed in the city of Ostrava, Czech Republic, which provided an innovative planning solution that improves the quality of peoples' lives by implementing crowdsourcing within the strategic urban planning process. The presented case can serve as a good practice example of government's intention to listen to peoples' suggestions, problems and needs, to involve the latter in effective participation in the strategic urban planning process. Using Ostrava as a case study, this paper will show how crowdsourcing can be utilized in improving urban planning.

The rest of the paper is structured as follows. Section 2 presents a brief literature review of research works on the use of crowdsourcing in strategic urban development planning. Section 3 describes the research method. This is followed by a case study in Section 4. Finally, Section 5 reports on findings and provides conclusions.

\section{LITERATURE REVIEW}

The following literature will focus on aspects with direct relevance to the topic of local government's use of crowdsourcing to support citizens' participation. The first major area of this review is the extent to which public officials use crowdsourcing. Some researchers have examined how crowdsourcing supports citizens' participation. The literature review will, therefore, analyse the research relating to how public officials are using crowdsourcing tools to build and strengthen the relationship and encourage civic engagement.

\subsection{Strategic urban development planning}

Gordon (2013) defines strategic development planning as a systematic process by which a community anticipates and plans for its future. The main outcome of the strategic planning process is the strategic development plan, being defined as a plan that identifies critical priorities and outcomes to be achieved by the municipality over a longer term. The strategic plan is, therefore, a basic conceptual and development document created by an urban or municipal authority based on the current state of public and private activities, of demographic, economic, social, cultural and environmental nature within the city. The main purpose of the strategic development plan is the organization of development on the basis of balancing individual interests so that the city thrives as a whole, providing a certain orientation for business entities in setting their longerterm business plans.

The plan must be both visionary and strategic. It outlines goals and objectives for the future and is the principal guide directing land use policy and decision-making. It defines the policies, programs and specific actions necessary to attain these objectives, prepares the city for growth, and provides a reliable basis for public and private investment.

The first step when building a solid plan is to open the lines of communication. It includes the staff, managers and directors, city council, and last but not least, the citizens. The city managers should engage and collaborate with the inhabitants as much as possible to know that the plan fo- 
cuses on the right initiatives. According to Wamsler (2016), improving the city-citizen collaboration is an important step in fostering transformative adaptation. One possible way to provide an innovative planning solution that facilitates the communication and collaboration with citizens is the implementation of crowdsourcing.

\subsection{Crowdsourcing}

The term crowdsourcing was first coined by Howe (2006) as the act of a company or institution taking a function once performed by employees and outsourcing it to an undefined (and generally large) network of people in the form of an open call. It has many definitions but can be unified by the idea of an open call for anyone to participate in an online task (Estelles-Arolas \& Gonzalez-Ladron-De-Guevara, 2012;Brabham, 2013) by contributing information, knowledge or skills. In the public participation context, it is stated that crowdsourcing "involves an organization-user relationship whereby an organization executes a top-down, managed process that seeks the bottom-up, open, creative input of users in an online community", and it is this management that makes it "productive and full of potential to do good" (Brabham, 2013).

Despite the phenomenon of crowdsourcing it was primarily developed in the field of business, however as it is emerging, the applications of crowdsourcing for various activities are expanding (Hossain \& Kauranen, 2015). The first author who demonstrated that crowdsourcing can be effectively used in public sector as a particular form of citizen participation in the public policy processes was Brabham (2009). According to him, crowdsourcing happens when: (1) an organization has a task to perform, (2) an online community voluntarily perform the task, and (3) the result is a mutual benefit for the organization and the online community.

Schenk \& Guittard (2011) defined three different components in every crowdsourcing initiative, namely: (1) an organization which benefits, directly or indirectly from the crowd's wisdom, (2) individuals who form the crowd and are responsible for generating the content, and (3) crowdsourcing enablers who serve as an intermediary platform, building the link between these two. The organization component in this context is urban government, the crowd component refers to citizens as a part of online community, and the platform is the technology which plays a vital role as a facilitator (Zhao \& Zhu, 2014), (Aitamurto, Landemore, \& Saldivar Galli, 2017).

\subsection{Crowdsourcing for strategic urban development planning}

To make appropriate decisions that reflect the overall wishes and needs of population, it makes sense to refer to citizens (Garcia, Vivacqua, \& Tavares, 2011). That is why many cities actively seek new methods to engage their population as a partner in the urban planning processes (Rowe \& Frewer, 2000).

The citizen participation has been facilitated and made easier through a widespread and easy access to technologies such as the Internet, mobile phones and other communication devices enabling public officials to harness the collective intelligence of the crowd in ways face-to-face planning meetings cannot (Shirky, 2008; Sowmya \& Pyarali, 2014). Crowdsourcing, in this way, proved itself to be an appropriate model for enabling the citizen participation process in public planning projects (Brabham, 2009) as it creates opportunities to improve popular participation 
in the public sector (Layne \& Lee, 2001), as well as increases the population's expectations regarding public services' reach.

Crowdsourcing is particularly suitable for urban planning because it voluntarily brings together a large group of people to address common issues that affect them. As stated by Brabham (2009), crowdsourcing works successfully for local purposes through localized knowledge and acquired experiences because people in a city tend to identify themselves with the place where they live, and socialize, and are generally more interested in the systems that affect them (Erickson, 2010). What is more, citizens are better aware of problems occurring in their neighbourhood. Last but not least, involving citizens can lead to outcomes that are more widely accepted by future users (Burby, 2003).

Researchers have long emphasized the importance of public participation in the planning process as a critical component to the successful implementation of any plan (Innes, 1998), (Burby, 2003). Broad public participation leads to "greater legitimization and acceptance of public decisions, greater transparency, and efficiency in public expenditures, and greater citizens' satisfaction” (Insua, Kersten, Rios, \& Grima, 2008). According to Burby (2003), inclusion of stakeholders with varied interests and different background makes a plan comprehensive, acceptable, and more easily implementable. Moreover, a participatory planning process effectively recognizes that "society is pluralist and there are legitimate conflicts of interest that have to be addressed by the application of consensus building methods" (Hague et al., 2003). With these traits in mind, participatory planning has the potential to involve broader and more diverse groups of people into a planning dialogue, and hence, can bring in newer perspectives and ideas to the planning problem at hand (Rabinowitz, 2013).

Using crowdsourcing is, therefore, popular and widespread democratic means of letting people take part in municipal urban planning with the dual goal of creating better policies and activation citizens' interest in public issues (Lehdonvirta \& Bright, 2015). Crowdsourcing in urban planning can thus be seen as one of the latest so-called democratic innovations - that is, processes and tools designed to increase and deepen citizen participation in public processes (Smith, 2009).

In crowdsourcing for urban planning, the crowd is asked to submit knowledge, ideas and perspectives. This input is then synthetized and incorporated as needed into the strategic-planning process (Aitamurto et al., 2017). If implemented right, crowdsourcing can complement traditional participation methods, and ameliorate many of difficulties in participation programs for urban government while bringing new insights and innovation to a public problem.

\subsection{Benefits of crowdsourcing}

It has been stated by many scholars that crowdsourcing is an appropriate model for enabling citizen participation process in urban planning project. To argue for its capabilities for citizen participation in planning projects, they state the following benefits.

According to Zuccon et al. (2013), crowdsourcing provides urban governments with an opportunity of reaching higher a number of participants (it enables to harness collective intelligence among population in ways face-to-face meetings cannot (Brabham, 2009)) and exploit citizens' 
knowledge (citizens have rich knowledge of their concerns) to develop innovative solutions to increasingly serious and complex societal problems. This is confirmed by Royo \& Yetano (2015), who state that crowdsourcing enables municipalities to take advantage of citizens' knowledge to find solutions to pre-defined problems.

Besides helping to solve local problems, the fact of engaging a crowd of people to address complex issues save the administration money (Schweitzer, Buchinger, Gassmann, \& Obrist, 2013; Royo \& Yetano, 2015) and lead to more legitimate choices as it results in the design of better, more socially rooted, balanced and realistic policies (Spiliotopoulou, Charalabidis, N. Loukis, \& Diamantopoulou, 2014). This is confirmed by Zuccon et al. (2013), who, proved that crowdsourcing enables to reach a higher number of participants and provides results as valuable as those furnished by traditional methods, at half the cost and collecting five times more data.

Moreover, crowdsourcing allows a citizen to influence the topics to be included in the urban planning agenda (Royo \& Yetano, 2015), and it opens a new form of community building for government (Koch, Füller, \& Brunswicker, 2011) as a consequence of new relationships that arise between the administration and the crowd, including citizens' building-up of social capital and a greater sense of local identity on the part of citizens (Collm \& Schedler, 2012). Therefore, it increases citizens' participation and engagement (Spiliotopoulou et al., 2014), (Tapscott, Williams, \& Herman, 2008).

Last but definitely not least benefit is that it promotes transparency and accountability as well as reduces corruptions, enabling urban government to open up large quantities of activity and spending related data (Spiliotopoulou et al., 2014).

It can, therefore, be concluded that crowdsourcing can be used as an alternative to traditional methods, allowing more cost-effective initiatives that lead to a greater quantity of collected data as it fosters the civic engagement.

\subsection{Crowdsourcing for civic engagement}

Citizen e-participation in urban governance is defined by Silva (2014) as the ubiquitous use of ICTs to support citizens' involvement in the urban policy process in its different stages, without limits of time and space, through processes of information, consultation or an active participation, being crowdsourcing in urban governance a specific mode of active e-participation. As stated by many scholars (Macintosh, 2004;Fung, 2006;Albrecht et al., 2008; Alt, Shirazi, Schmidt, Kramer, \& Nawaz, 2010), the value of e-participation is closely linked to the level of citizens' engagement.

The move from off-line and paper-based urban governance to a mode based largely on digital and online environments requires new working methods and new tools (Silva, 2014) such as innovative Web 2.0 applications (Casey \& Li, 2012), user generate content applications, citizens' consultation platforms, central portals for petitions, social computing platforms, geo-visualization and geo-location technologies (Anttiroiko, 2012), and mobile applications (Sundstrom, 2012). Although these tools are now opening new channels and possibilities for communication between citizens and government, offering new possibilities for data collection, information and consultation in urban governance, many scholars (Moody, 2007), (Sieber, 2008) agree that they should not be seen as a 
replacement of conventional modes of citizens' participation in urban governance, but should be seen rather as a complement to traditional participatory methods and tools.

Although in most cases e-participation is part of a wider participatory process that also includes non-virtual and off-line activities, the tendency seems to be for public officers using little by little the new e-participation tools as they allow simpler, inexpensive, less time-consuming and a more effective way of interaction with citizens, and thus fostering citizen engagement in urban governance (Silva, 2014).

\section{OBJECTIVES AND METHODOLOGY}

The objective of this article is to provide a description and deep explanation of the process of using crowdsourcing as one of the tools for strategic urban development plan creation process and events occurring within a specific case of Ostrava city. First, the literature review was performed. Secondly, the case study is presented with the main focus on the crowdsourcing tools used such as the online questionnaire survey being conducted in February 2016. The results are complemented by findings from interviews with the city officials and guarantors of the strategic development plan preparation being held in April 2016.

\section{CASE STUDY: THE USE OF CROWDSOURCING FOR STRA- TEGIC URBAN DEVELOPMENT PLANNING IN OSTRAVA}

The city of Ostrava, encompassing an area of 214 square kilometres, is one of the largest municipalities in the Czech Republic located in the northeast of the country. Recently, the city of almost 300,000 inhabitants, known as an industrial centre of the Czech Republic, was facing negative effects of the depopulation along with its population aging. The city has undertaken to change this tendency and to resolve this problem in the new strategic plan.

\subsection{Main identified problems according to statistics}

One of the main problems identified was that the city of Ostrava is being depopulated. According to statistics, there are lower birth rates and a higher mortality tendency in the past years. The life expectancy in Ostrava is lower by about 2, 8 years for men and 1,6 years for women compared to Brno although the age structure of population leads rather to the opposite or at least less negative expectations.

Tab. 1 - The proportion of live births per 1,000 inhabitants. Source: FajnOVA

\begin{tabular}{|l|l|l|}
\hline Live births / 1,000 inhabitants & $2005-2009$ & $2010-2014$ \\
\hline Czech Republic & 10.7 & 10.5 \\
\hline Moravian-Silesian Region & 10.3 & 9.8 \\
\hline Ostrava & 10.9 & 10.2 \\
\hline Brno & 11.5 & 11.7 \\
\hline Pilsen & 10.8 & 10.3 \\
\hline
\end{tabular}


Tab. 2 - The proportion of deceased per 1,000 inhabitants. Source: FajnOVA

\begin{tabular}{|l|l|l|}
\hline Live births / 1,000 inhabitants & $2005-2009$ & $2010-2014$ \\
\hline Czech Republic & 10.1 & 10.2 \\
\hline Moravian-Silesian Region & 10.3 & 10.8 \\
\hline Ostrava & 10.8 & 11.3 \\
\hline Brno & 10.6 & 10.2 \\
\hline Pilsen & 10.2 & 10.4 \\
\hline
\end{tabular}

Moreover, there is a big difference between the number of people moving to the city and those moving out of the city. As observed from the tables below, in the years 2010-2014, the balance was evicted -5.67 people per 1,000 inhabitants.

Tab. 3 - The proportion of those moving in the city per 1,000 inhabitants. Source: FajnOVA

\begin{tabular}{|l|l|l|}
\hline People moved in / 1,000 inhabitants & $2005-2009$ & $2010-2014$ \\
\hline Czech Republic & 6.7 & 2.9 \\
\hline Moravian-Silesian Region & 4.6 & 3.6 \\
\hline Ostrava & 13.3 & 13.0 \\
\hline Brno & 22.3 & 20.8 \\
\hline Pilsen & 28.5 & 21.4 \\
\hline
\end{tabular}

Tab. 4 - The proportion of those moving out of the city per 1,000 inhabitants. Source: FajnOVA

\begin{tabular}{|l|l|l|}
\hline People moved out / 1,000 inhabitants & $2005-2009$ & $2010-2014$ \\
\hline Czech Republic & 1.8 & 1.7 \\
\hline Moravian-Silesian Region & 5.6 & 6.1 \\
\hline Ostrava & 16.9 & 18.7 \\
\hline Brno & 21.1 & 23.6 \\
\hline Pilsen & 20.4 & 21.0 \\
\hline
\end{tabular}

The negative effect of depopulation goes together with another significant problem which is the fast aging of population. Although currently, Ostrava has a slightly more favourable age structure than Brno and Pilsen, the proportion of people aged 65+ per one-person aged 0-14 increased in the last 5 years by $11.0 \%$ in Ostrava, while in Pilsen it went up by only $1.8 \%$, and even fell in Brno by $-0.2 \%$. 
Tab. 5 - The proportion of the population aged 0-14 in the Czech Republic, Moravia-Silesian Region, Ostrava, Brno and Pilsen in 2010 and 2014. Source: FajnOVA

\begin{tabular}{|l|l|l|l|}
\hline Proportion of the population 0-14 & 2010 & 2014 & Growth (\%) \\
\hline Czech Republic & 14.4 & 15.2 & 5.4 \\
\hline Moravian-Silesian Region & 14.4 & 14.7 & 2.7 \\
\hline Ostrava & 14.0 & 14.5 & 3.1 \\
\hline Brno & 13.1 & 14.4 & 10.4 \\
\hline Pilsen & 12.9 & 14.1 & 9.5 \\
\hline
\end{tabular}

Tab. 6 - The proportion of the population aged 15-64 in the Czech Republic, Moravia-Silesian Region, Ostrava, Brno and Pilsen in 2010 and 2014. Source: FajnOVA

\begin{tabular}{|l|l|l|l|}
\hline Proportion of the population 15-64 & 2010 & 2014 & Growth (\%) \\
\hline Czech Republic & 70.1 & 67.0 & -4.4 \\
\hline Moravian-Silesian Region & 70.5 & 67.7 & -3.9 \\
\hline Ostrava & 70.1 & 67.3 & -4.0 \\
\hline Brno & 69.1 & 65.9 & -4.6 \\
\hline Pilsen & 69.3 & 66.0 & -4.7 \\
\hline
\end{tabular}

Tab. 7 - The proportion of the population aged 65+ in the Czech Republic, Moravia-Silesian Region, Ostrava, Brno and Pilsen in 2010 and 2014. Source: FajnOVA

\begin{tabular}{|l|l|l|l|}
\hline Proportion of the population 65+ & 2010 & 2014 & Growth (\%) \\
\hline Czech Republic & 15.5 & 17.8 & 14.9 \\
\hline Moravian-Silesian Region & 15.2 & 17.5 & 15.4 \\
\hline Ostrava & 15.8 & 18.2 & 15.0 \\
\hline Brno & 17.9 & 19.7 & 10.2 \\
\hline Pilsen & 17.8 & 19.9 & 11.4 \\
\hline
\end{tabular}

Last, but not least important problem identified is the level of education in the competitor cities compared. According to statistics, the population of Ostrava is becoming smarter. Nevertheless, it is lagging behind in comparison with the population of Brno and Pilsen. As it can be observed from the table below, the proportion of undergraduates in Ostrava compared to the reference cities is lower; however, it grew by 36. 6\% during 2001-2011, while in Brno by $31.8 \%$ and in Pilsen by $24.1 \%$. Concerning those being trained and those with elementary education, the share of is higher in Ostrava. 
Tab. 8 - The proportion of population according to its education level in 2011. Source: FajnOVA

\begin{tabular}{|l|l|l|l|l|l|}
\hline Proportion of the population 15+ & Ostrava & Brno & Pilsen & M-S Reg. & Czech \\
\hline Elementary and no education & 19.2 & 13.2 & 14.3 & 20.1 & 18.0 \\
\hline $\begin{array}{l}\text { Secondary education (apprenticeship } \\
\text { certificate) }\end{array}$ & 31.8 & 23.2 & 28.7 & 35.1 & 33.0 \\
\hline Secondary education (baccalaureate) & 26.0 & 29.4 & 30.4 & 25.9 & 27.1 \\
\hline Follow-up study education & 2.6 & 3.2 & 3.1 & 2.6 & 2.8 \\
\hline Higher specialized education & 1.1 & 1.6 & 1.5 & 0.9 & 1.3 \\
\hline University education & 14.4 & 23.6 & 15.6 & 11.2 & 12.5 \\
\hline Not found out & 5.1 & 5.7 & 6.3 & 4.1 & 5.3 \\
\hline
\end{tabular}

\subsection{Planning context}

The purpose of the strategic development plan is to satisfy the needs of present and future residents. Thus, when Ostrava decided to create a new strategic development plan, the city officials were determined to involve as many citizens as possible in the preparation process to gain their opinion. The aim of engaging the city population to the plan creation process was to identify the main problems from the citizens' point of view, and to set out a clear, collective vision for the city, with an ambition to respond to the negative tendency of depopulation and to prevent citizens from moving out of the city.

This means that the city of Ostrava will focus on certain areas and regularly follow up and evaluate them to ensure a positive development for the municipality. "The strategic development plan will make it easier to see that we are doing the right things for the residents of the municipality," says Konczyna, the guarantor of the strategic development plan. As stated by the city mayor Macura appealing to citizens to participate in the crowdsourcing challenge: "We create a plan for people, so they should be a natural part of its preparation. We do not create a plan that will end up in the drawer. We create a plan for the city and its inhabitants, for those who live, work and have fun here, as well as for their children who want to live in Ostrava. If you are interested in what direction Ostrava is going to take in the next years to come and would like to participate in the development of the city, become a part of it. I am deeply convinced that our city has a great and untapped potential for development and it is only up to us, whether and how much we would use it." (Macura, 2016)

Ostrava launched its strategic development planning process in 2016. Multiple teams worked together to gather input from citizens (not only through crowdsourcing, but also by the way of visioning sessions, surveys, and focus groups), and to define the city's core products, services, and key customers.

\subsection{Development of the strategic plan}

The creation of the plan can be divided into six phases. First, in the preparatory phase (winter, end of 2015 and beginning of 2016), the city officials planned the timing, set up management 
and organizational structures, created stakeholder analysis, risk analysis, processing plan, and communication and participation plans. The aim was to find ideas about the final outcome and to set out how to get the result.

Secondly, in the analytical part (spring 2016), the existing strategic and conceptual materials on the territory of the city were mapped. The aim of this phase was to collect inputs from target groups, add them to external development trends and compare these to other cities. Within this phase, the city wanted to engage not only experts but also the public. Therefore, the fajnOVA (The brand fajnOVA combines two key elements, namely fajn which is a local dialect word meaning "fine, and OVA which is a commonly used abbreviation of the city's name.) brand was created as a communication tool for the preparation and implementation phases of the strategic plan, and the website www.fajnova.cz was launched, where current information and interesting facts about the creation of the plan were available. People could join it for the first time in February by completing an online questionnaire. Simultaneously, working groups were set up, professional and public discussions or interviews with experts were performed. There were also many interesting events in which people were able to express their own ideas about the future of Ostrava or come up with their own specific suggestions to change the city for the better. The aim of this phase was to formulate the main findings of the analysis from the perspective of the internal and external environment, problems and challenges, and set up a tree of problems and opportunities.

In the third phase (summer 2016), based on the data input from the analysis, the working groups, and their strategic discussion, the vision had been formulated. Next phase (summer 2016) was planning itself. At this stage, the key areas of strategic interventions, and the implementation of the strategic plan were defined after being discussed with working groups and key actors.

In autumn 2016, the proposal to implement the plan was made. The action plan, financial plan, monitoring process, evaluation and implementation structure was proposed, and the measurable indicators to meet defined strategic interventions were set up.

Last, but not least phase was the plan approval (Winter 2016/2017). In this phase, the background of the approval of the strategic plan, action plan and implementation plan were prepared by the city authorities. Finally, the plan, dubbed "FajnOVA", was adopted by the city council in August 2017 (FanjOVA, 2017).

\subsection{Plan creation: using crowdsourcing to gain citizens' point of view}

Going back to the analytical phase, the city wanted to engage not only experts but also the public and thus decided to use crowdsourcing. As the ambition of the strategic urban development plan was not only to offer an analytical view on different areas of life in the city of Ostrava based on objective data, the city representatives decided to address the public to gain their opinion (Macura, 2016). The analysis based on statistical data, benchmarking with selected cities (Brno and Pilsen), and interviews with personalities were therefore complemented with conclusions of the questionnaire survey. 


\section{Questionnaire survey}

The online questionnaire survey was designed to determine the perception of the quality of life in Ostrava. The survey was carried out online and held for 17 days in the period from 3rd to 19th February 2016. The respondents volunteered to participate in the inquiry upon the invitation of the city mayor. The questionnaire was distributed electronically by various communication channels, and the research data were collected by four specific ways: a) via direct e-mail sent to the companies based in Ostrava, to the employees of the Regional Office of the Moravian-Silesian Region, the Office of the Regional Council, the City of Ostrava, and 23 urban districts, as well as to all primary and secondary schools in the city, b) by publishing a challenge on the Ostrava website (www.ostrava.cz) and the project website (www.fajova.cz), c) by sharing a challenge on the project Facebook profile (fb.com/fajnova.cz) and 111 other Facebook profiles with a total of 1,003,112 members, and d) by organic spreading (Štefková, 2016). The questionnaire contained predominantly closed responses. Within 17 days, 43,310 Facebook users were reached out, and we recorded 7,170 unique website visitors and 728 "likes" on Facebook (Štefková, 2016).

Based on these activities, a total of 8,890 questionnaires were collected. These were subsequently cleared by incomplete responses, responses with apparently fictitious or logically impossible answers, and responses with no or almost no assessment of the current situation in Ostrava. Therefore, the final sample size was 6,827 questionnaires.

The structure of respondents according to sex and age was $52.1 \%$ women and $47.9 \%$ men of which $26.0 \%$ were aged from 25 to $34,24.0 \%$ from 35 to $44,17.7 \%$ from 45 to $54,1207 \%$ from $55-64,12.6 \%$ from 15 to $24,6.6 \%$ of respondents were older than 65 years, and $0.5 \%$ of respondents were younger than 14 .

The structure of respondents according to their job title was as follows: $30.4 \%$ employees in a private company, $27.1 \%$ employees in public sector, $12.4 \%$ employers and entrepreneurs, $9.2 \%$ pensioners, $8.3 \%$ university students, $3.7 \%$ college or primary school students, $2.9 \%$ people on maternity or parental leave, $2.6 \%$ employees in the non-profit sector, $1,7 \%$ unemployed, and $1.7 \%$ others.

Concerning the structure of respondents according to their domicile, $80.8 \%$ of them stated living in Ostrava, while 18. 1\% live out of the city but still in the Moravian-Silesian. Region, 1. $0 \%$ live out of the region but still in the Czech Republic, and only $0.2 \%$ claimed to live abroad (this was the case of university students only).

As one of the main problems identified in Ostrava was the depopulation. The purpose of the questionnaire survey was to find out its causes. The results show that $23.6 \%$ of adult respondents claimed that they are considering moving out of the city within ten years. Almost one quart of the productive population (adults and families with children) is considering the emigration from Ostrava, when $14.1 \%$ of them are planning to move to the city surroundings not farther away than 30 minutes by car.

More alarming is the fact that the young are considering moving out of the city more often than the adults. According to the survey, 59. 1\% pupils and college students respond that after studying, they planned to live elsewhere than in Ostrava. The same tendency is observed the group of university students. Only $53.3 \%$ of them are planning not to stay in the city, while $36.8 \%$ want to move out of the Moravian-Silesian Region. 
The most frequent reasons for moving out of Ostrava were, according to the preferences of adults, as follows: those who want to move within the city surroundings mentioned the air quality, safety, proximity of nature, noise and transport, a higher quality of living in a house, presence of hostels and non-compliant citizens. Those, who want to move out of the surroundings of Ostrava speak about the air quality, job opportunities and wages, noise, non-adaptive citizens (the clime of the community), security, cultural activities in larger cities, better quality of life while living in a house. The last group of respondents planning to move out of Ostrava are those who want to go abroad most often because of job opportunities and wages, leisure opportunities in larger cities, air quality, security and composition of the inhabitants of Ostrava.

The most frequent reasons for moving out of the city of Ostrava were, according to the pupils and college students as follows: better job opportunities in Brno, Prague or abroad, better entertainment possibilities, the image of the preferred cities and experience from living abroad. University students claim that they want to move out because of better job opportunities, a more favourable composition of the population, possibilities of richer leisure time activities, better environment, city appearance, negatively perceived possibilities of Ostrava's future development, more suitable places starting a family, and experience from living abroad.

The aim of the questionnaire survey was also to find out how citizens are satisfied with their lives in the city. The average satisfaction rate with life in Ostrava is $64 \%$. In the graph below, the distribution of responses is presented.

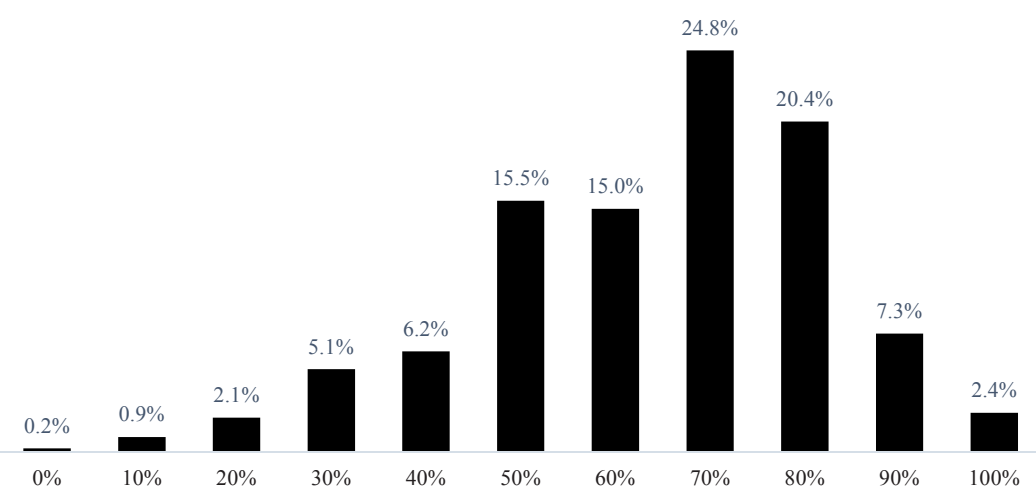

Fig. 1 - The degree of satisfaction: distribution of responses. Source: FajnOVA

Looking closer at individual areas, the greatest satisfaction among different groups of inhabitants is with education, health and social services and transport. These areas are discussed in more detail below. On the contrary, people are least satisfied with the quality of the environment, the culture of inhabitants' behaviours, and with security. In some groups, the least satisfaction is also found with job opportunities and cleanliness as well the image of public spaces. 
The quality of the environment (water, air, etc.) Culture of population behavior

Feeling of security in the city Cleanliness and appearance of public spaces Employment opportunities Image of urban area Image of city Ostrava Quality of living Quality of municipal services
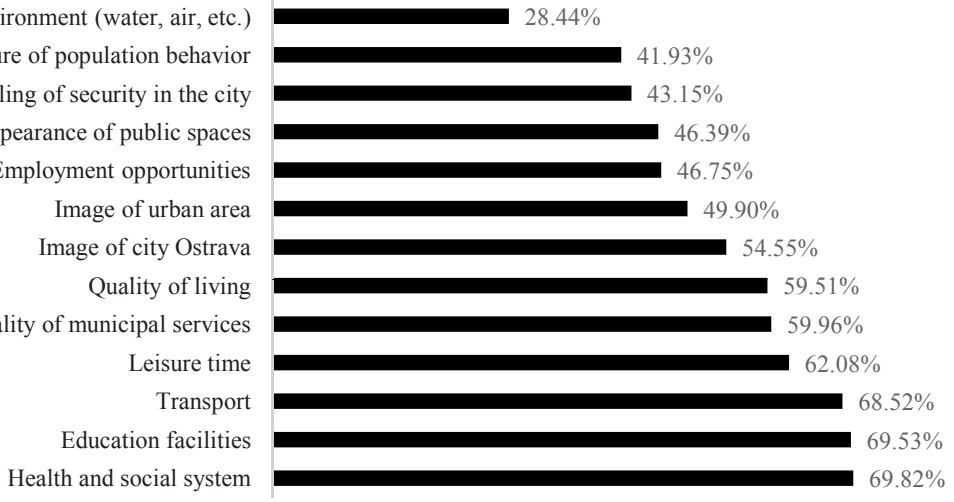

Fig. 2 - Question: Rate your overall satisfaction with the following areas of life in Ostrava. Source: FajnOVA

Respondents were also asked to list 1-3 areas they consider to be the greatest priorities of Ostrava's development in the coming years. They have unanimously agreed to improve the quality of the environment and security in the city. As it can be observed, respondents also agreed to improve the cleanliness image of public spaces, parking possibilities, development of parks and rest zones, and job opportunities.

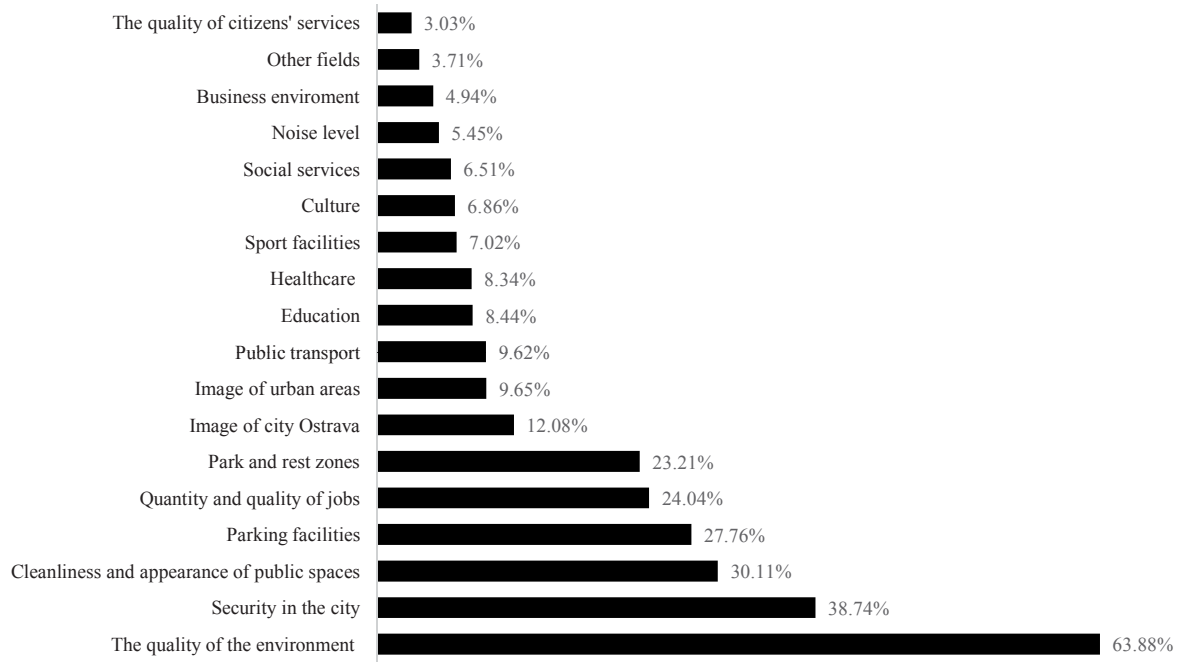

Fig. 3 - Question: Choose 1-3 areas you want to improve in the following years. Source: FajnOVA

One part of the questionnaire survey inquired about the level of satisfaction with the business factors in the city of Ostrava. As it can be observed from the charts below, businesspeople worry most about the workforce and the image of Ostrava. 


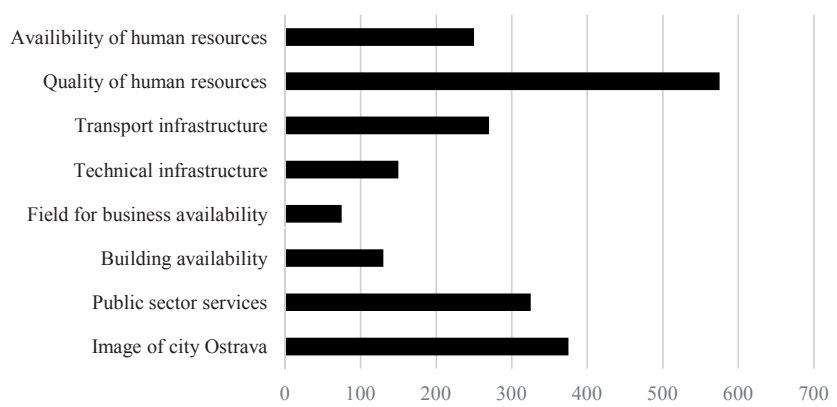

Fig. 4-Question: Choose areas where improvement is the most important in business terms in the coming years. Source: FajnOVA

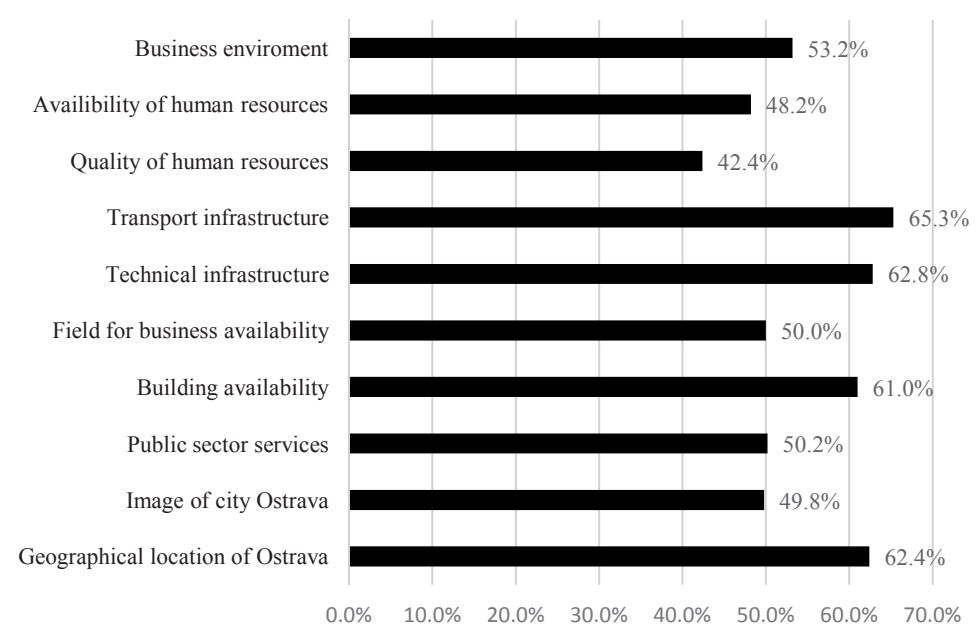

Fig. 5 - Question: Rate your overall satisfaction with the following areas of life in Ostrava. Source: FajnOVA

The entrepreneurs are most satisfied with transport infrastructure, technical infrastructure and access to business. On the contrary, they are not satisfied with the quality of the workforce and the image of the city. These are factors, together with public sector services, which they have identified as priorities for further development.

\subsection{Implementation of the results into the strategic plan}

As mentioned, the results from the questionnaire survey were complemented by other inputs from the target groups (focus groups, in-depth structured interviews with key actors), and integrated with the external development trends. After that, the main findings in terms of the analysis of internal and external environments, problems and challenges were formulated. Finally, the vision and seven strategic goals to be achieved by the strategic plan were formulated. These are: (1) Building an interconnected city, (2) Revitalizing the historic city centre, (3) Being a centre 
for top-quality education, (4) Enhancing the business environment, (5) Supporting communities and citizens' involvement in public life, (6) Creating a great environment for all generations, and (7) Bringing the city closer to nature.

The three key success indicators for the strategic development plan were formulated as follows: (1) Inward migration to Ostrava will be stable or growing, as the demographic structure of population will improve, reversing the current trend of depopulation. Young, educated or economically active people will make up a larger percentage of the city's total population. (2) Average pre-tax wages in Ostrava and the Moravian-Silesian Region will grow more rapidly. (3) Air pollution in Ostrava will be reduced (Palička, 2017).

The Ostrava City Strategic Development plan 2017-2021 was approved in January 2017. It was created through the collaborative efforts of experts, public figures and citizens from Ostrava. This case study is a good practice example of how the crowdsourcing can be used to involve citizens in urban planning.

\section{CONCLUSION}

In preparation of the strategic development plan for the city of Ostrava, the municipal council realized that an active participation from residents was both desirable and necessary. To ensure that a broad cross-section of issues and perspectives from a wide range of individuals were represented, they decided to use crowdsourcing as one of the tools used within the process of the plan creation. While for many cities, a strategic plan is often only a formal document, the new strategic development plan in Ostrava was created by involving a wide range of actors, including the public. In total, more than 6,800 people completed an online questionnaire giving their opinions on Ostrava, almost 1,200 people put 15,300 comments into the online emotional map, 500 people sent the city officials their ideas for projects and suggestions for the strategic plan, and more than 3,250 people are members of the FajnOVA Facebook community (Palička, 2017). Thus, there was a great potential to create a living document and a platform for cooperation between the public, private, academic and non-profit spheres to help to set Ostrava's long-term course.

As can be observed from the case study, the strategies put forward in the plan were intended to assist policymakers in ensuring that the future development and planning proposals meet the expectations of the citizens. It can be therefore concluded that the vision has been accomplished.

In Ostrava, public officials applied crowdsourcing within the strategic development planning process to allow citizens to express their concerns and needs. In this context, the public officials took the citizens input seriously and took them into account when creating the strategic development plan. As has been demonstrated, crowdsourcing can be seen as one step further towards greater civic participation, in which citizens can directly participate in the governance process.

Several questions for further research emerge from this study. While my research examines the use of crowdsourcing tools, more needs to be known about the peoples' motivations for participating in the challenge. Crowdsourcing can facilitate but not create citizens' engagement, and so it would be useful to understand the motivational factors as well as the extent to which citizens participate. Finally, the use of crowdsourcing in the public sector raises questions about why 
some cities outperform others, and a further analysis is needed to understand the critical success factors associated with higher rankings on the civic engagement index.

\section{References}

1. Aitamurto, T., Landemore, H., \& Saldivar Galli, J. (2017). Unmasking the crowd: participants' motivation factors, expectations, and profile in a crowdsourced law reform. Information, Communication \& Society, 20(8), 1239-1260. http://dx.doi.org/10.1080/ 1369118X.2016.1228993.

2. Albrecht, S., Kohlrausch, N., Kubicek, H., Lippa, B., Märker, O., Trénel, M., . Wiedwald, C. (2008). eParticipation - electronic participation of citizens and the business community in eGovernment. Study on Behalf of the Federal Ministry of the Interior (Germany), Division IT, 1. Institut für Informationsmanagement Bremen.

3. Alt, F., Shirazi, A. S., Schmidt, A., Kramer, U., \& Nawaz, Z. (2010). Location-based crowdsourcing: extending crowdsourcing to the real world. Paper presented at the 6th Nordic Conference on Human-Computer Interaction: Extending Boundaries, Reykjavik, Iceland. http://dx.doi.org/10.1145/1868914.1868921.

4. Anttiroiko, A. V. (2012). Urban Planning 2.0. International Journal of E-Planning Research (IJEPR), 1(1), 1 16-30. http://dx.doi.org/10.4018/ijepr.2012010103.

5. Boukhris, I., Ayachi, R., Elouedi, Z., Mellouli, S., \& Amor, N. B. (2016). Decision Model for Policy Makers in the Context of Citizens Engagement: Application on Participatory Budgeting. Social Science Computer Review, 34(6), 740-756. http://dx.doi.org/10.1177/089443 9315618882.

6. Brabham, D. C. (2009). Crowdsourcing the public participation process for planning projects. Planning Theory, 8(3), 242-262. http://dx.doi.org/10.1177/1473095209104824.

7. Brabham, D. C. (2013). Using Crowdsourcing In Government. IBM Center for the Business of Government. http://dx.doi.org/10.1177/1473095209104824.

8. Burby, R. J. (2003). Making plans that matter: Citizen involvement and government action. Journal of the American Planning Association, 69(1), 33-49.

9. Casey, C., \& Li, J. (2012). Web 2.0 Technologies and Authentic Public Participation: Engaging Citizens in Decision Making Processes. University of Texas at Arlington, USA. http://dx.doi. org/10.4018/978-1-4666-0318-9.ch011.

10. Collm, A., \& Schedler, K. (2012). Managing crowd innovation in public administration. International Public Management Review, 13(2), 1-18.

11. Desouza, K. C., \& Bhagwatwar, A. (2014). Technology-enabled participatory platforms for civic engagement: the case of US cities. Journal of Urban Technology, 21(4), 25-50. http:// dx.doi.org/10.1080/10630732.2014.954898.

12. Dirks, S., \& Keeling, M. (2009). A vision of smarter cities: How cities can lead the way into a prosperous and sustainable future. IBM Institute for business Value, 8.

13. Erickson, T. (2010). Geocentric crowdsourcing and smarter cities: Enabling urban intelligence in cities and regions. Paper presented at the 1st Ubiquitous Crowdsourcing Workshop at UbiComp. 
14. Estellés-Arolas, E., \& González-Ladrón-de-Guevara, F. (2012). Towards an integrated crowdsourcing definition. Journal of Information Science, 38(2), 189-200. http://dx.doi. org/10.1177/0165551512437638.

15. FajnOVA (2017, April). Strategický plán. Retrieved September 18, 2017, from http:// fajnova.cz/strategicky-plan/.

16. Fung, A. (2006). Varieties of participation in complex governance. Public Administration Review, 66(1), 66-75. http://dx.doi.org/10.1111/j.1540-6210.2006.00667.x.

17. Garcia, A. C. B., Vivacqua, A. S., \& Tavares, T. C. (2011). Enabling Crowd Participation in Governmental Decision-making. J. UCS, 17(14), 1931- 1950.

18. Gooch, D., Wolff, A., Kortuem, G., \& Brown, R. (2015). Reimagining the role of citizens in smart city projects. Paper presented at the Adjunct Proceedings of the 2015 ACM International Joint Conference on Pervasive and Ubiquitous Computing and Proceedings of the 2015 ACM International Symposium on Wearable Computers. http://dx.doi. org/10.1145/2800835.2801622.

19. Gordon, G. L. (2013). Strategic planning for local government. ICMA Publishing.

20. Hague, C., Kirk, K., Higgins, M., Prior, A., Jenkins, P., Smith, H., Grimes, W. (2003). Participatory planning for sustainable communities.

21. Hossain, M., \& Kauranen, I. (2015). Crowdsourcing: a comprehensive literature review. Strategic Outsourcing: An International Journal, 8(1), 2-22. http://dx.doi.org/10.1108/SO-122014-0029.

22. Howe, J. (2006). The Rise of Crowdsourcing - Forget outsourcing. The new source of cheap labor is everyday people using their spare cycles to create content, solve problems, even do RD. Wired, 14(6), 176.

23. Innes, J. E. (1998). Information in communicative planning. Journal of the American Planning Association, 64(1), 52-63. http://dx.doi.org/10.1080/01944369808975956.

24. Insua, D. R., Kersten, G. E., Rios, J., \& Grima, C. (2008). Towards decision support for participatory democracy. Information systems and e-business management, 6(2), 161-191.

25. Koch, G., Füller, J., \& Brunswicker, S. (2011). Online crowdsourcing in the public sector: how to design open government platforms Online Communities and Social Computing. Springer. http://dx.doi. org/10.1007/978-3-642-21796-8_22.

26. Layne, K., \& Lee, J. (2001). Developing fully functional E-government: A four stage model. Government Information Quarterly, 18(2), 122-136. http://dx.doi.org/10.1016/S0740624X(01)00066-1.

27. Lehdonvirta, V., \& Bright, J. (2015). Crowdsourcing for public policy and government. Policy \& Internet, 7(3), 263-267. http://dx.doi.org/10.1002/poi3.103.

28. Macintosh, A. (2004). Characterizing e-participation in policy-making. Paper presented at the System Sciences, 2004. Proceedings of the 37th Annual Hawaii International Conference. http://dx.doi.org/10.1109/HICSS.2004.1265300.

29. Macura, T. (2016). Strategický plán může být i vaším dílem. Retrieved 36.9.2017, from https://www.ostrava.cz/cs/o-meste/aktualne/strategicky-plan-muze-byt-i-vasim-dilem. 
30. Mladenow, A., Bauer, C., \& Strauss, C. (2014). Social Crowd Integration in New Product Development: Crowdsourcing Communities Nourish the Open Innovation Paradigm. Global Journal of Flexible Systems Management, 15(1), 77-86. http://dx.doi.org/10.1007/s40171013-0053-6.

31. Moody, R. (2007). Assessing the role of GIS in e-government: A tale of e-participation in two cities. Electronic Government, 354-365. http://dx.doi.org/10.1007/978-3-540-74444-3_30.

32. Palička, V. (2017). Ostrava City Strategic Development Plan 2017-2023. Ostrava: Retrieved from http://fajnova.cz/wp-content/uploads/2017/03/Ostrava_City_Strategic_Plan.pdf.

33. Rabinowitz, P. (2013). Participatory approaches to planning community interventions. The Community Tool Box.

34. Rowe, G., \& Frewer, L. J. (2000). Public participation methods: A framework for evaluation. Science, technology, \& human values, 25(1), 3-29. http://dx.doi.org/10.1177/016224 390002500101.

35. Royo, S., \& Yetano, A. (2015). "Crowdsourcing” as a tool for e-participation: two experiences regarding CO2 emissions at municipal level. Electronic Commerce Research, 15(3), 323-348. https://doi.org: 10.1007/s10660-015-9183-6. http://dx.doi.org/10.1007/s10660015-9183-6.

36. Shirky, C. (2008). Here comes everybody: The power of organizing without organizations. Penguin.

37. Schenk, E., \& Guittard, C. (2011). Towards a characterization of crowdsourcing practices. Journal of Innovation Economics \& Management, 0 (1), 93-107. http://dx.doi.org/10.3917/ jie.007.0093.

38. Schweitzer, F., Buchinger, W., Gassmann, O., \& Obrist, M. (2013). Crowdsourcing: leveraging innovation through online idea competitions. IEEE Engineering Management Review, 41(3), 24-32. http://dx.doi.org/10.1109/emr.2013.6596543.

39. Sieber, R. (2008). Participatory Geoweb: A research agenda. Paper presented at the Proceedings of the Spatial Knowledge and Information Canada Conference (SKI-Canada).

40. Silva, C. N. (2014). Open Source Urban Governance. Citizen E-Participation in Urban Governance, 1-18. http://dx.doi.org/10.4018/978-1-4666-4169-3.ch001.

41. Smith, G. (2009). Democratic innovations: designing institutions for citizen participation: Cambridge University Press. http://dx.doi.org/10.1017/CBO9780511609848.

42. Sowmya, J., \& Pyarali, H. S. (2014). The Effective Use of Crowdsourcing in E-Governance: Nanyang Technological University, Singapore. Accessed January 2014.

43. Spiliotopoulou, L., Charalabidis, Y., N. Loukis, E., \& Diamantopoulou, V. (2014). A framework for advanced social media exploitation in government for crowdsourcing. Transforming Government: People, Process and Policy, 8(4), 545-568. http://dx.doi.org/10.1108/ TG-01-2014-0002.

44. Sundstrom, L.-M. (2012). i-Government. Citizen 2.0: Public and Governmental Interaction through Web 2.0 Technologies, 297-308. http://dx.doi.org/10.4018/978-1-4666-03189.ch015. 
45. Surowiecki, J., \& Silverman, M. P. (2007). The wisdom of crowds. American Journal of Physics, 75(2), 190-192.

46. Štefková, E. (2016). Dotazníkové šetření: metodika. www.fajnova.cz.

47. Tapscott, D., Williams, A. D., \& Herman, D. (2008). Government 2.0: Transforming government and governance for the twenty-first century. New Paradigm, 1, 15.

48. Wamsler, C. (2016). From Risk Governance to City-Citizen Collaboration: Capitalizing on individual adaptation to climate change. Environmental Policy and Governance, 26(3), 1842014.

49. Zhao, Y., \& Zhu, Q. (2014). Evaluation on crowdsourcing research: Current status and future direction. Information Systems Frontiers, 16(3), 417-434. http://dx.doi.org/10.1007/ s10796-012-9350-4.

50. Zuccon, G., Leelanupab, T., Whiting, S., Yilmaz, E., Jose, J. M., \& Azzopardi, L. (2013). Crowdsourcing interactions: using crowdsourcing for evaluating interactive information retrieval systems. Information retrieval, 16(2), 267-305. http://dx.doi.org/10.1007/s10791-0129206-z.

\section{Contact information}

Mgr. Ing. Barbora Haltofova

Tomas Bata University in Zlin, Faculty of Management and Economics

Mostni 5139, 76001 Zlin, Crech Republic

E-mail: haltofova@fame.cz. 